\title{
Introducing Multidisciplinary Perspectives to the Adjudication of Indigenous Rights
}

\author{
Kristin Henrard \& Jeremie Gilbert*
}

This special issue focuses on adjudication of indigenous peoples' rights. In the last decades, indigenous peoples' engagement with litigation has become a global phenomenon, with more and more indigenous communities engaging with court processes to get their rights recognised. Although for a long time litigation was mainly concentrated in post-colonial settlers' societies such as Canada, Australia and New Zealand, the last few years have witnessed a notable increase in indigenous peoples' recourse to courts across the globe. This is part of the larger 'process of juridification' of indigenous peoples' politics, and the increased legal adjudication of indigenous claims. ${ }^{1}$

The changes are not only in the numbers of cases of litigation, but also relates to the cross-fertilisation in the arguments put forward in these cases (by both parties and the courts themselves). As noted by the UN Expert Mechanism on the Rights of Indigenous Peoples (EMRIP), many national courts have refereed and relied on international norms in their litigation, notably the UN Declaration on the Rights of Indigenous Peoples (UNDRIP). ${ }^{2}$ Furthermore, and relatedly, there is an increasing development of a transnational, global jurisprudence on indigenous peoples' rights, with courts increasingly citing cases across jurisdictions.

Most of these cases concern indigenous peoples' rights to land and natural resources, and more particularly their rights to consultation and consent. This increase in litigation is the sad reflection of the mounting pressure that is put on indigenous peoples' territories, with a view to exploit natural resources, often going hand in hand with 'land grabbing'. ${ }^{3}$ Last year has been one of

* Kristin Henrard is professor minorities and fundamental rights in the department of International and EU law of the Erasmus School of Law in the Netherlands. Jeremie Gilbert is professor of Human Rights Law at the University of Roehampton in the UK.

1. See S. Kirsch, 'The Juridification of Indigenous Politics', in J. Eckert, B. Donahoe, C. Strümpell \& Z. Biner (eds.), Law against the State: Ethnographic Forays into Law's Transformations (Cambridge: Cambridge University Press, 2012); K.A. Carpenter and A.R. Riley, 'Indigenous Peoples and the Jurisgenerative Moment in Human Rights', California Law Review 102 (2014), at 173.

2. Report of the Expert Mechanism on the Rights of Indigenous Peoples: Ten years of the implementation of the United Nations Declaration on the Rights of Indigenous Peoples: good practices and lessons learned 2007-2017, UN Doc. A/HRC/36/56 (7 August 2017)

3. See J. Gilbert, 'Land Grabbing, Investors, and Indigenous Peoples: New Legal Strategies for an Old Practice?', 51(3) Community Development Journal 350 (2016), at 350-66; S. Smis, D. Cambou \& G. Ngende. 'The Question of Land Grab in Africa and the Indigenous Peoples' Right to the most violent years against land rights defenders, including indigenous peoples who were murdered for their engagement in protecting their lands and territories. ${ }^{4}$ In reaction many indigenous communities and supportive non-governmental organisations (NGOs) have taken recourse to adjudication.

Litigation usually comes after long years of unsuccessful negotiations, bad faith on the part of the authorities, and often direct violations of indigenous peoples' rights by corporations or investors. As a consequence, indigenous communities turn to litigation as a last resort to assert their rights and obtain remedies. It is within such context of increasing recourse to adjudication and litigation that this special edition places itself.

\section{Scope of the Special Edition}

While it appears that litigation comes often as last resort, when all other means of protests and resistance have been used, it is important to highlight the manifold kinds of impacts of this litigation, that go beyond the material remedies sought in the form of land title and monetary compensation. The special edition of the journal also places itself within a time of reflection on the (actual) impact of litigation, as it discusses both the different possible types of impacts of litigation and the limitations, challenges and potential pitfalls of litigation. While the special issue stands on itself, several interesting links can be made with the findings of a recent study commissioned by the Open Society Justice Initiative on the impact of strategic litigation regarding indigenous peoples' land rights (OSJI study). ${ }^{5}$ The following discussion of the OSJI report and the different ways in which this special issue relates to the report enable us to locate the special issue in the broader literature on indigenous rights, while providing an extra platform for the OSJI report.

Traditional Lands, Territories and Resources', 35 Loyola of Los Angeles International and Comparative Law Review (2012), at 493.

4. Seie Global Witness, 'Defenders of the Earth: Global Killings of Land and Environmental Defenders in 2016' (Global Witness, 2017), available at: <https://www.globalwitness.org/en/campaigns/environmentalactivists/defenders-earth>.

5. J. Gilbert, 'Strategic Litigation Impacts: Indigenous Peoples' Land Rights' (Open Society Justice Initiative, April 2017), available at: <https://www. opensocietyfoundations.org/reports/strategic-litigation-impactsindigenous-peoples-land-rights>. See further infra for a summary of some of the principal findings of the OSJI report. 
While highlighting that litigation on land rights is now a global phenomenon, the OSJI study focused on the situation in Malaysia, Kenya and Paraguay, countries which have witnessed a significant level of litigation on land rights. The study highlights the obstacles of litigation to secure the land rights of indigenous peoples, inter alia due to the burden of proof required by courts and the resistance of the dominant social and political climate. The latter also results in judgments in favour of indigenous peoples not being implemented.

Importantly, the OSJI study identifies and distinguishes different types of impact, which may explain why indigenous peoples continue to turn to litigation notwithstanding the aforementioned drawbacks and challenges. The most obvious impact concerns material outcomes (both direct - related to restitution, and indirect financial compensation and thus access to socio-economic rights). In addition, there are also immaterial impacts, related to a change in attitudes, both among the indigenous peoples and external stakeholders. A third type of impact pertains to ensuing legal and policy changes. In terms of legal changes, this points to the power of courts to develop the law through their interpretation and application of the law in concrete cases and to the importance of non-state actors as instigators of cases. ${ }^{6}$

To some extent these impacts pertain to the communities engaging in litigation themselves, but to some extent the impacts go further. Litigation is indeed seen to have an empowering impact on the indigenous peoples themselves, who become more aware of their rights. In addition, the (successful) litigation experience by a particular community may have ripple effects: it may inspire other communities to engage in litigation, also due to the change in attitudes of other relevant stakeholders, while the legal reasoning of one (international) court may also be persuasive for another faced with a similar case. Furthermore, also among the judiciary shifts in attitudes towards indigenous peoples can be noted, which in turn can translate into the aforementioned ripple effects.

In some respects the articles in this special issue 'continue' the research focus in the OSJI report, ${ }^{7}$ while in others, the special issue adds layers of analysis to those in the OSJI report, ultimately furthering the goal of the OSJI report to get a $360^{\circ}$ perspective on the adjudication of indigenous (land) rights.

In line with the OSJI report and the range of effects of litigation that it highlights in its main findings, several articles in the special issue have extensive attention for the role of courts in the shaping of the law, both nationally and transnationally, courts shaping the law through interpretation. Furthermore, the current special issue

6. See also K. Henrard, Revisiting the Role of Non-State Actors and International Courts in the Making of International (Customary) Law: General Considerations and the Case of Indigenous Peoples Land Rights, Leuven Centre for Global Governance Studies WP 196, December 2017.

7. Interestingly, several of the authors in this special issue were part of the contributors to the Report. builds and adds to some of the main findings of the OSJI report, namely: ${ }^{8}$

1. In most situations, legal pleadings on behalf of indigenous peoples did not begin as 'strategic litigation' per se. Previously inchoate or discrete litigation efforts were typically made more 'strategic' over time by being deployed together with other advocacy tools, generating progressive jurisprudence that could benefit others. It was not until the cases reached a higher court (either nationally or internationally) that they were viewed as possible vehicles for social change beyond the interests of individual claimants.

2. There is usually a lack of implementation, but the OSJI study highlights that even if implementation was absent, winning a case proved to be significant at all three levels of impact. The positive rulings put potent political tools into the hands of the indigenous communities that they probably could not have wielded had they not brought suit. ... the fact of a win in court prompted positive feelings of empowerment, rights awareness, and self-advocacy (non-material impacts). Sometimes, a win inspired other communities to file, generating more broad-based pressure on the courts to address systemic rights violations. ...

3. ... litigation promoted a new interpretation of the law to counteract the lack of land rights recognition. ... the judiciary interpreted the existing legal framework in ways that enhanced the integration of indigenous customary land rights. ...

4. ... strategic litigation substantially improved rights awareness and of legal empowerment among concerned communities. The way the communities organised, and the degree to which they were united (or not) played crucial roles in affecting whether cases were successful, and whether positive judgments were ultimately implemented.

5. Strategic litigation influenced attitudes and behaviour toward indigenous peoples' right of land among external stakeholders as well. For example, it prompted civil society organisations and donors to lend the community their support, leading to the development of joint post-litigation advocacy strategies among mainstream civil society actors who might not have engaged with indigenous peoples previously and provision of development funds.

All these findings and conclusions are verified by the articles compiled in this special edition. At the same time this special edition takes a broader approach to litigation to examine to what extent implementation, or lack of it, carries any impact on the choice to go to court. Indeed, the articles in this special issue are trying to 'locate' the use of litigation among the other strategies used by the concerned communities. Furthermore, the special issue adds layers to the analysis in the OSJI report, in terms of countries covered, multidisciplinary perspectives included, the in-depth analysis of questions

8. OSJI Report, at 5-7 
of mapping and cartography and the attention for the range of actors involved in the adjudication processes.

\section{Structure and Approaches of the Special Edition}

The special issue adopts a multidisciplinary approach, which is felt necessary to properly answer the many complex questions that indigenous peoples' rights trigger. Indeed questions about the burden of proof, the scope of the relevant (fundamental) rights, the determination of adequate remedies (and the related measurement of damages) cannot be properly answered from one particular disciplinary perspective only. A multidisciplinary approach enables the problems and hardships of indigenous peoples to be more suitably captured, which in turn benefits the just adjudication of their claims, and ultimately also the impact on the ground of judgments in favour of indigenous peoples. For example, one of the articles in this special issue focuses on legal geography: showing how through adjudication and implementation an interrelation is produced between law and space. Another addition concerns the attention for an essential prerequisite to litigating indigenous land rights, more particularly mapping and cartography.

Second, the special issue also acknowledges the value of including practitioners, so as to take their rich, accumulated experience through their involvement with actual cases into account. The special issue furthermore highlights the role of NGOs and more generally the necessary collaboration between NGOs and local communities to support and enhance community-led litigation strategies.

The special issue takes off with two articles focusing on the 'preliminary' questions of obtaining sufficient proof in order to get to court.

In the first article, Jérémie Gilbert and Ben BegbieClench analyse how indigenous peoples usually face a very high level of proof, as courts and tribunals are usually putting the burden on the indigenous claimants to prove their rights. As they examined, this is often very challenging for indigenous peoples who are lacking formal and official land titles. Based on their experience with supporting litigation in Namibia and Uganda, they explore how community mapping has become an important element of the litigation strategy. In doing so they examine the value of these community mapping exercise, not only for their legal value in the court cases, but also as a tool for legal empowerment and knowledge sharing.

Building on the importance of cartography and mapping, Kristen Anker's article explores how Aboriginal communities in Canada have managed to challenge the traditional and conservative approach to legal evidence using their own cultural maps to mark their ancestral territories. In doing so she offers a very compelling analysis on the role of cartography to challenge the govern- mental dominant assumptions about 'empty' land and the narrative of 'efficient' and agricultural use of the territories. Using historical and contemporary cases of litigation, the article highlights the importance of recognising the value of aboriginal peoples' own perceptions of land and natural resources, notably advocating for the use and recognition of Aboriginal art as an evidence of land titles. The article highlights how indigenous peoples' approaches to land and natural resources are, and how these connections are expressed in their arts, including songs, performance and oral traditions, which all represent an expression of indigenous customary laws that are still not properly respected and integrated by the domain legal systems.

The special issue then turns to three articles focusing on the impact of the jurisprudence of international courts, while taking on board additional perspectives, either in terms of disciplinary perspectives and/or having special regard to the range of actors that are involved and influence the adjudication processes.

Fergus Mackay, who as a lawyer has supported indigenous peoples in several cases before the inter-American Court of Human Rights (IACtHR), closely analyses the case of the Kaliña and Lokono peoples against Surinam, a case triggered by the (impact of) mining and logging operations, as well as the establishment of nature reserves, and individual titles on the territory of the peoples concerned. Fergus Mackay starts by highlighting the findings by the IACtHR of numerous violations of the American Convention on Human Rights, all of which can be related to the lack of recognition of indigenous peoples as legal persons (capable of holding collective property titles) and the lack of effective remedies for the protection of collective property rights.

Fergus Mackay goes on to develop several arguments with a strong legal flavour. He highlights the mutual interplay of various fields of public international law when he underscores the extent to which the court draws on international environmental law and the UN Guiding Principles on Business and Human Rights, while clarifying the rights of indigenous peoples (in relation to environmentally protected areas). Most of all though, he highlights the cross-fertilisation and related blurring of the lines between soft and hard law, when he focuses in his analysis on the extent to which the InterAmerican Court uses UNDRIP to guide its interpretation of the American Convention on Human Rights. The weight of a UN Declaration, which is not legally binding, gets substantially stronger when it guides the interpretation of a legally binding instrument. However, the court does not only develop the interpretation of the latter convention, it also further shapes the interpretation of the UN Declaration, by clarifying the provisions of the Declaration and adding detail. A red thread throughout Mackay's analysis is the recognition of the significant role of (the IACtHR and other) international courts in the shaping of international law. In turn, this speaks to the importance of strategic litigation as a means of further developing indigenous rights standards. 
Joel Correia's article continues the focus on the interAmerican human rights system, but shifts emphasis to the way in which the national courts struggle to translate the judgments of the Inter-American Court into changes in the law on the ground, more particularly focusing on three cases in Paraguay. The reflection on the after-effects of adjudication follows the perspective of legal geography, an interdisciplinary approach that investigates the mutual constitution of law and space with keen attention to how that relationship shapes the limits and possibilities for social justice. This article thus further expands the multidisciplinary perspectives gathered in this special issue.

Joel Correia highlights the importance of not stopping at the analysis of promising judgments by (international) courts but also to consider the actual implementation (or lack thereof) on the ground, as the latter also fundamentally impacts victims' lives, and the effective enjoyment of their rights while influencing the actual relation between space and law.

Joel discusses three cases brought by indigenous peoples in relation to their ancestral lands before the IACtHR, all of which were successful in the sense that this court found multiple violations of indigenous peoples' rights in relation to their ancestral lands. These three cases reveal how a legal framework that is positive at first sight, and promises a strong protection of indigenous 'land rights', is de facto frustrated by historical and structural factors related to different understandings, different notions, different importance attached to 'territory'. The more economic (rational use) perspective adopted by the state contrasts with the more identityinfused' notion of territory that prevails for indigenous peoples. The former understanding goes hand in hand with land having been sold to private foreign investors, and the disproportionate politico-economic power of the agro-export industry, both ultimately frustrating the indigenous peoples' special relationship with their ancestral lands. This dynamics also negatively impacts Paraguay's timely or effective compliance with the rulings of the IACtHR, thus confirming and exacerbating the marginalisation of the indigenous communities concerned.

The third article zooming in on the jurisprudence of international courts turns to the African human rights system. Lucy Claridge, one of the leading lawyers in the case of Kenya's Ogiek indigenous people, highlights in her article the importance that the engagement with litigation has created in terms of legal empowerment of the community concerned, thus adding a socio-legal perspective. She starts her account with painting the history of dispossession and marginalisation of the Ogiek, who have been routinely subjected to forced evictions from their ancestral land in the Mau Forest without consultation or compensation, thus being prevented from practising their traditional hunter-gatherer way of life. Following unsuccessful national litigation efforts, the Ogiek, supported by an international NGO, brought a case before the African human rights system.
Claridge discusses extensively the claims by the Ogiek, the government's response and ultimately the reasoning and findings of the African Court on Human and Peoples' Rights. Strikingly, the court in its first case on indigenous peoples, found in relation to the Ogiek's forced evictions of their ancestral lands multiple violations of the African Charter on Human and Peoples' Rights, not only of the right to property (Article 14), the right not to be discriminated against (Article 2) and the freedom to worship (Article 8), but also the right to their own culture (Article 17), the right to freely dispose of their wealth and natural resources (Article 21), and their right to development (Article 22).

Claridge goes on to underscore how the case, and the proof that needed to be collected and submitted, also provided an opportunity for community engagement and legal empowerment: the Ogiek have become more aware of their human rights and also united in their joint struggle. In this respect her account of this specific case supports the main findings in the OSJI report.

Her article is also a testimony of the necessary collaboration between NGOs, lawyers and local partners to support and enhance community-led litigation strategies, as the former ensure close consultations of the indigenous peoples throughout the litigation process.

In their article concerning the situation in Malaysia, Yogeswaran Subramaniam and Colin Nicholas highlight how courts have been instrumental in recognising indigenous peoples' land rights. Across Malaysia, including in Sabah and Sarawak, indigenous peoples have suffered from forced displacement and serious loss of access to their land and natural resources notably due to a lack of legal recognition of their fundamental rights to land in the national legal system. This has pushed many communities to seeking legal remedies using courts. The two authors have been involved in many of these cases supporting indigenous peoples' legal arguments in front of the courts. In their article they share their experience with the courts, highlighting the steps forward but also the drawbacks created by litigation. In doing so, they engaged in a comparative analysis on the limitations offered by the legal pronouncements of courts based solely on common-law principles of aboriginal and native title. As in Malaysia recourse to international law is extremely limited, the common-law doctrine that has emerged from Australia and Canada has been used as the main source of legal recognition of indigenous peoples' customary land rights. However, as the two authors, activists and legal advocates argue in their article, there are some serious limitations to such approach. From this perspective, this article about the legal situation in Malaysia is not only relevant in the context of Malaysia, but for many indigenous peoples who are also relying on common-law approach to indigenous peoples' land rights.

The special edition includes a conversation, or a series of interviews, with two prominent advocates and litigators on indigenous peoples' rights. Based on a series of questions on the role and place of litigation, Beatriz Barreiro Carril asks Gordon Bennet about his involvement 
in cases of litigation, notably in Botswana, to support indigenous peoples' land rights. The interview provides some enlightening statements from Gordon, who has worked for more than 30 years in the defence of indigenous peoples' rights as a lawyer. This is followed by an interview with Stephen Corry who has been the director of the NGO Survival International for many years, in his interview Stephen highlights the complexity, the challenges, but also the prospects, of supporting litigation as a tool in pushing for changes.

Finally, in a powerful afterword, Stuart Kirsch, an anthropologist who has been involved in many cases of litigation to support indigenous peoples' rights, offers some overall analysis on the interaction between indigenous peoples, lawyers, civil society organisations and judges. He highlights many of the shortcomings that are inherent in the formal process of litigation, and the drawbacks that are created by the lack of understanding and cultural connections between the different actors involved. The afterword also highlights how litigation can offer a positive platform to challenge the dominant legal systems, and support future changes.

It is hoped that the special issue will thus contribute to the emerging reflection on the potential role that courts and tribunals can play to support the rights of indigenous peoples. 